\title{
Absorption Studies of Arsenic Using Maghemite Crystals Synthesized from Iron Waste Extracted from Ogun State Iron Mill Dumpsite
}

\author{
John Adeola Adegoke, I. Adegoke Halimat \\ University of Ilorin, Ilorin, Nigeria \\ Email: jadegoke89@yahoo.com
}

Received 5 December 2015; accepted 13 March 2016; published 16 March 2016

Copyright (C) 2016 by authors and Scientific Research Publishing Inc.

This work is licensed under the Creative Commons Attribution International License (CC BY). http://creativecommons.org/licenses/by/4.0/

(c) (i) Open Access

\begin{abstract}
This paper outlines the synthesis of maghemite from raw iron waste obtained in an iron mill dumpsite around Ogun state, Nigeria. Magnetite was synthesized from the ferrous precursor obtained by digesting the iron waste with concentrated $\mathrm{H}_{2} \mathrm{SO}_{4}$. Transformation of magnetite to maghemite was done by heating the magnetite obtained in an oven at $200^{\circ} \mathrm{C}$. To determine the absorption capacity of the synthesized maghemite sample, a stock solution of As(III) was used for the absorption. Absorption spectrum shows higher absorption of $\gamma-\mathrm{Fe}_{3} \mathrm{O}_{4}$ at higher concentration of $\mathrm{As}(\mathrm{III})$. Maximum absorption obtained is $14 \mathrm{mg} / \mathrm{g}$. Estimated yield of $\gamma-\mathrm{Fe}_{3} \mathrm{O}_{4}$ was $32 \%$; however a low, further study promises to improve the yield value. The study shows $\gamma-\mathrm{Fe}_{3} \mathrm{O}_{4}$ to be a good absorbent for heavy metals.
\end{abstract}

\section{Keywords}

Atomic Absorption, Maghemite, Arsenic, Iron Waste

\section{Introduction}

Iron oxide generally exists in different structures and forms with different useful applications ranging from geological to nanoscale technology; the most common however are $\alpha-\mathrm{Fe}_{2} \mathrm{O}_{3}$ (hematite), $\gamma-\mathrm{Fe}_{2} \mathrm{O}_{3}$ (maghemite), $\mathrm{Fe}_{3} \mathrm{O}_{4}$ (magnetite) and $\mathrm{Fe}_{1-\mathrm{x}} \mathrm{O}$ (wustite); the less commonly found are $\beta$ - and $\varepsilon-\mathrm{Fe}_{2} \mathrm{O}_{3}$ [1]. Maghemite has the same crystalline structure like $\mathrm{Fe}_{3} \mathrm{O}_{4}$ (magnetite). Main distinct features of maghemite are the presence of vacancies in Fe position with symmetry reduction. These basic polymorphs, the cubic bixbyite structure "beta" and orthor- 
hombic structure "epsilon”, as well as nanoparticles of all forms, have been synthesized and extensively investigated in recent years [2]. Out of all these polymorphs, magehmite is the iron oxides currently most studied, which exhibits ferrimagnetic behavior below $1000 \mathrm{~K}$ due to the super exchange integrals competition between tetrahedral and octahedral sites and lately, it has found considerable uses in magnetic resonance imaging, magnetic recording media, fabrication of biocompatible magnetic fluids, and electrochromic devices [1] [3]. Much focus has been given to it resulting in the modification in the growth, crystal structure, magnetic and electrical properties

However, a present review of the various synthesis methods available for maghemite nanoparticles growth shows co-precipitation, thermal decomposition, hydrothermal synthesis, microemulsion, sonochemical synthesis, and sonochemical as the most common methods; other methods such as electrochemical synthesis, laser pyrolysis techniques are not common [4]. Considering the present and the future prospect of maghemite crystals, it becomes highly needful to develop a simple, cheap and sustainable method for the synthesis of maghemite nanoparticles.

Metals are natural components of the environment including soil but they are of great concern when they are being added continuously. Nigeria as a country has a lot of iron mining and other allied iron processing companies. Unfortunately, only few of these companies have a standard way of disposing their waste iron scrap. This has a devastating effect on the environment with a long-term impact [5] [6]. The aim of this study is to carry out an absorption study on Arsenic stock solution using synthesized maghemite from the iron scrap which has an absorbent.

\section{Experiment Details}

\subsection{Preparation of Ferrous Precursor}

Experiment was carried out according to Legodi et al. (2007) [7]. Iron scrap obtained from a factory dumpsite in Ogun state, Nigeria was grinded and sieved to obtain a fine iron particle. $60 \mathrm{~g}$ of this sieved iron water was digested with $300 \mathrm{ml}$ of concentrated $\mathrm{H}_{2} \mathrm{SO}_{4}$ until a turbid solution was observed and further heated to dryness. This was used as a ferrous precursor.

\subsection{Preparation of Maghemite from Ferrous Precursor}

$20 \mathrm{~g}$ of the ferrous precursor was added to $120 \mathrm{ml}$ of deionized water. The mixture was stirred gently. A green precipitate solution of $\mathrm{Fe}^{2+}$ was formed and filtered off. $25 \% \mathrm{NH}_{4} \mathrm{OH}$, prepared by making up $25 \mathrm{ml}$ of concentrated ammonia in a $100 \mathrm{ml}$ standard flask with deionized water was added to the filtrate and allow to age for 20 hours and filtered before washing with deionized water. On drying, a crystalline, fine, black particle of magnetite was obtained. Finally, the magnetite obtained above was oven heated at $200^{\circ} \mathrm{C}$ for two hours according to the equation below (Equation (2.2)). Maghemite particles, with a light brown coloration were obtained. The experiment was performed inside a glove box to prevent any possible oxygen contamination

$$
\begin{gathered}
3 \mathrm{Fe}^{3+}+4 \mathrm{NH}_{4} \mathrm{OH}+3 \mathrm{H}_{2} \mathrm{O} \rightarrow \mathrm{Fe}_{3} \mathrm{O}_{4}+4 \mathrm{NH}_{3}+3 \mathrm{H}_{2} \mathrm{O}+8 \mathrm{H}^{+} \\
\mathrm{Fe}_{3} \mathrm{O}_{4} \underset{200^{\circ} \mathrm{C}}{\longrightarrow} \gamma-\mathrm{Fe}_{2} \mathrm{O}_{3}+\mathrm{FeO}
\end{gathered}
$$

\subsection{Sorption Experiment}

Two batches (A and B) of various standards, 10, 20, 30, 40, 50, 100, 200, 300, 400, 500, and 1000 ppm of As(III) solution was prepared. Batch A was taken as the standard solutions with which the amount of As(III) sorbed were referenced $0.5 \mathrm{~g}$ of the maghemite particles synthesized was weighed into each concentration of the second batch and stirred vigorously in a mechanical stirrer until complete dispersion was observed. Atomic absorption spectrophotometry was used in determining the actual concentration of As(III) in both batches.

\section{Result and Discussion}

The absorption data obtained for both batches are tabulated as in Table 1 and Table 2.

The concentration of As(III) in the stock after the absorption was also determine and the result is presented in Table 3. Using the Equation (3.1) below, the amount of As absorbed by the maghemite sample can be evaluated. The amount $Q_{\text {sorbed, }}$ is also tabulated below: 
Table 1. Absorbance of As(III) obtained with different concentration (Batch A).

\begin{tabular}{ccc}
\hline S/N & Standards (ppm) & Absorbance \\
\hline 1 & 10 & 0.60 \\
2 & 20 & 0.70 \\
3 & 40 & 0.75 \\
4 & 50 & 0.80 \\
5 & 100 & 0.95 \\
6 & 200 & 1.15 \\
7 & 300 & 1.30 \\
8 & 400 & 1.35 \\
9 & 500 & 1,45 \\
10 & 1000 & 1.60 \\
\hline
\end{tabular}

Table 2. Absorbance of As(III) obtained with different concentration + maghemite (Batch B).

\begin{tabular}{ccc}
\hline S/N & Standards $(\mathrm{ppm})$ & Absorbance \\
\hline 1 & 10 & 0 \\
2 & 20 & 0.02 \\
3 & 40 & 0.07 \\
4 & 50 & 0.13 \\
5 & 100 & 0.53 \\
6 & 200 & 0.63 \\
7 & 300 & 0.72 \\
9 & 400 & 0.85 \\
10 & 500 & 1.15 \\
\hline
\end{tabular}

Table 3. Amount of As(III) sorbed (mg/g) at different concentration.

\begin{tabular}{ccccc}
\hline S/N & Standards & Absorbance & Concentration & $Q_{\text {sorbed }}(\mathrm{mg} / \mathrm{g})$ \\
1 & 40 & 0.02 & 0 & 0 \\
2 & 50 & 0.07 & 0 & 0 \\
3 & 100 & 0.13 & 5 & 3.86 \\
4 & 200 & 0.53 & 15 & 5.8 \\
5 & 300 & 0.63 & 98 & 6.04 \\
7 & 400 & 0.72 & 130 & 7.4 \\
\hline
\end{tabular}




$$
Q_{\text {sorbed }}=\frac{v\left(C_{i}-C_{f}\right)}{m}
$$

where $Q_{\text {sorbed }}$ is the amount of maghemite iron adsorbed, $v$ is the volume of the stock solution taken for analysis, $C_{i}$ is the initial concentration of the $\mathrm{As}(\mathrm{III}), C_{f}$ is the final concentration of the As(III) after the absorption and $m$ is the mass of the maghemite sample used for the absorbtion experiment (Table 3).

A plot of $Q_{\text {sorbed }}(\mathrm{mg} / \mathrm{g}$ ) against concentration of arsenic (ppm) (see Figure 1) was used to determine the linear absorption of the maghmite samples. It could be seen that $Q_{\text {sorbed }}$ is directly proportional to the concentration of standard implying that more heavy metals such $\mathrm{As}, \mathrm{Cr}, \mathrm{Hg}$, $\mathrm{Pb}$, etc. could be easily removed with the method. Such heavy metals are found to be inherently laden in companies discharged waste and other heavy industrial waste dump. This technology can be improved to treat discharge waste of heavy metal and make them environmentally friendly.

Yield Calculation

Mass of iron waste used $60 \mathrm{~g}$

Mass of ferrous Precursors obtained after digestion $70 \mathrm{~g}$

Residue obtained after washing with excess water and filtering
This implies that Mass of $\mathrm{Fe}^{3+}$ that's dissolved $70 \mathrm{~g}-50.55 \mathrm{~g}$

Mass of Magnetite obtained after drying

From the equation of reaction (2.1 above),

3 moles of $\mathrm{Fe}^{3+}(168 \mathrm{~g} / \mathrm{mol}) 2$ moles of $\mathrm{Fe}_{3} \mathrm{O}_{4}(233 \mathrm{~g} / \mathrm{mol})$

$\Rightarrow$ Number of moles of $\mathrm{Fe}_{3} \mathrm{O}_{4}$ produced $=\left[(19.78 \mathrm{~g} \times 3 \mathrm{~mol}) / 168 \mathrm{~g} \cdot \mathrm{mol}^{-1}\right] / 3 \mathrm{~mol}$

$\Rightarrow$ Experimentally, 0.118 mole of $\mathrm{Fe}_{3} \mathrm{O}_{4}$ was obtained

$\Rightarrow 27.376 \mathrm{~g}$ (Molar mass of $\mathrm{Fe}_{3} \mathrm{O}_{4} \Rightarrow 232 \mathrm{~g} \cdot \mathrm{mol}^{-1}$ )

Percentage yield of $\mathrm{Fe}_{3} \mathrm{O}_{4}=\frac{9.02 \mathrm{~g} \text { of Magnetite obtained }}{27.376 \mathrm{~g} \text { therotical mass of magnetite }} \times 100 \% \Rightarrow 32.96 \%$

One mole $\mathrm{Fe}_{3} \mathrm{O}_{4}\left(232 \mathrm{~g} / \mathrm{mol}^{-1}\right) \Rightarrow$ one mole of $\left(160 \mathrm{~g} \cdot \mathrm{mol}^{-1}\right) \gamma-\mathrm{Fe}_{2} \mathrm{O}_{3}$ $\Rightarrow 9.02 \mathrm{~g}$ of $\mathrm{Fe}_{3} \mathrm{O}_{4} \Longrightarrow\left[9.02 \mathrm{~g} \times 160 \mathrm{~g} \cdot \mathrm{mol}^{-1}\right] / 232 \mathrm{~g} \cdot \mathrm{mol}^{-1} \Rightarrow 6.220 \mathrm{~g}$

Percentage of $\gamma-\mathrm{Fe}_{2} \mathrm{O}_{3} \Rightarrow \frac{6.220 \mathrm{~g} \text { of maghemite trasnformed }}{9.020 \mathrm{~g} \text { of magnetite }} \times 100 \% \Rightarrow 68.95 \%$

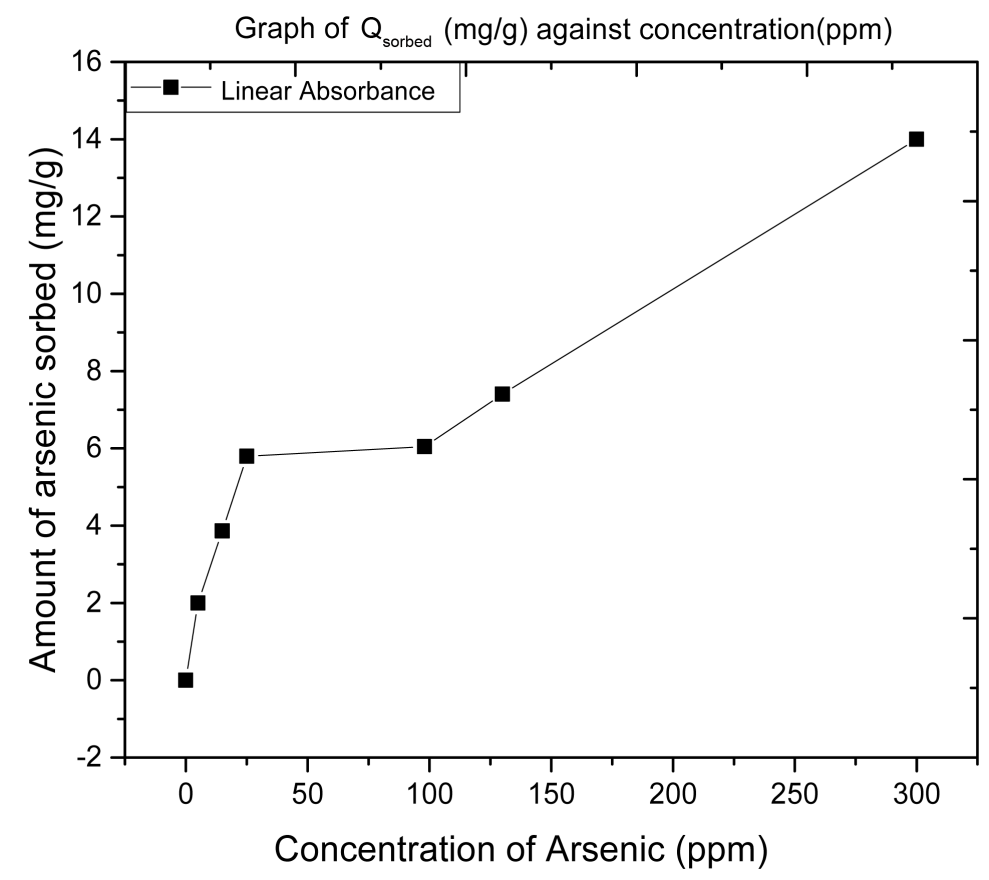

Figure 1. Graph of $Q_{\text {sorbed }}(\mathrm{mg} / \mathrm{g})$ against concentration (ppm). 


\section{Conclusion}

It has been shown that maghemite can be successfully synthesized from waste iron by transforming the magnetite obtained from the ferrous precursor. Sorption experiment proved maghemite to be a good absorbent for As(III). Other heavy metals such as $\mathrm{Cr}$, Pb, etc. were however not studied. The absorption was low at lower concentration (10, 20, 30, 40, 50 ppm). More As(III) were sorbed at higher concentration. Experimental yield obtained for mghmite finally synthesized was low (32\%). We believe that this can be improved with more studies. Heavy metals present in most water, waste and other environmental surfaces can be successfully removed at a low cost and pollution reduction.

\section{References}

[1] Martinez, A.I., Garcia-Lobato, M.A. and Perry, D.L. (2009) Study of the Properties of Iron Oxide Nanostructures. Research in Nanotechnology Developments, 19, 184-193.

[2] Chirita, M. and Grozescu, I. (2009) $\mathrm{Fe}_{2} \mathrm{O}_{3}$-Nanoparticles, Physical Properties and Their Photochemical and Photoelectrochemical Applications. Scientific Bulletin of "Politehnica" University of Timisoara, 54, 1.

[3] Wu, W., He, Q.G. and Jiang, C.Z. (2008) Magnetic Iron Oxide Nanoparticles: Synthesis and Surface Functionalization Strategies. Nanoscale Research Letters, 3, 397-415. http://dx.doi.org/10.1007/s11671-008-9174-9

[4] Restrepo, J., Labaye, Y. and Greneche, J.M. (2006) Magnetic Properties of Maghemite Nanoparticles: A HeisenbergMontecarlo Study. Colombian Journal of Physics, 38.

[5] Abdus-Salam, N. (2009) Assessment of Heavy Metals Pollution in Dumpsites in Ilorin Metropolis. Ethiopian Journal of Environmental Studies and Management (EJESM), 2, 92-99. http://dx.doi.org/10.4314/ejesm.v2i2.45926

[6] Okeyode, I.C. and Rufai, A.A. (2002) Determination of Elemental Composition of Soil Samples from Some Selected Dumpsites in Abeokuta, Ogun State, Nigeria, Using Atomic Absorption Spectrophotometer. International Journal of Basic \& Applied Sciences, 2, 55-70.

[7] Legodi, M.A. and de Waal, D. (2006) The Preparation of Magnetite, Goethite, Hematite and Maghemite of Pigment Quality from Mill Scale Iron Waste. Dyes and Pigments, 74, 161-168. http://dx.doi.org/10.1016/j.dyepig.2006.01.038 